\title{
Photo-ID as a tool for studying and monitoring the endangered Saimaa ringed seal
}

\author{
Meeri Koivuniemi ${ }^{1, *}$, Miina Auttila ${ }^{1,2}{ }^{,}$Marja Niemi $^{1}$, Riikka Levänen ${ }^{1}$, \\ Mervi Kunnasranta ${ }^{1}$
}

${ }^{1}$ University of Eastern Finland, Department of Biology, PO Box 111, 80101 Joensuu, Finland

${ }^{2}$ Metsähallitus, Parks \& Wildlife Finland, Akselinkatu 8, 57130 Savonlinna, Finland

\begin{abstract}
Photo-identification (photo-ID) with camera traps was examined as a non-invasive method for studying and monitoring the endangered Saimaa ringed seal Phoca hispida saimensis. An average of 51 game cameras were set up at shoreline haul-out sites in central Lake Saimaa during the moulting seasons in each of the years from 2010 to 2014. Individuals were identified from their lifelong unique lateral fur patterns. A total of 220000 digital images of seals were obtained from these game cameras and from digital cameras during this period, allowing 164 individuals to be identified, $43 \%$ of which were re-sighted in successive years. In the majority of game camera images, both sides of the seal were shown, and it was possible to determine the sex of the seal. The average distance between sightings of individual seals in different years was $1.6 \mathrm{~km}$, suggesting that Saimaa ringed seals exhibit a high degree of moulting site fidelity. In addition, the results support suggestions of natal site fidelity. We propose that photo-ID sampling based on camera traps, and larger-scale photographic survey of the seals, should be implemented as a population monitoring tool of the Saimaa ringed seal. Further application of the photo-ID technique may facilitate mark-recapture population and survival rate estimates for this threatened seal species and provide significant insights into its life history and social behaviour.
\end{abstract}

KEY WORDS: Camera trapping - Game cameras $\cdot$ Climate change $\cdot$ Phoca hispida saimensis Non-invasive $\cdot$ Population monitoring $\cdot$ Endangered species

\section{INTRODUCTION}

The endangered Saimaa ringed seal Phoca hispida saimensis is threatened by various anthropogenic factors, especially incidental bycatch and climate change (Kovacs et al. 2012, Liukko et al. 2015). Furthermore, an extremely low genetic diversity together with a small population size imply an elevated risk of extinction (Valtonen 2014). Current knowledge of the behavioural ecology of this endemic freshwater subspecies is mainly based on telemetric studies employing a relatively low number of animals (Kunnasranta 2001, Koskela et al. 2002, Niemi 2013). Saimaa ringed seals are relatively sedentary and exhibit high site fidelity for breeding and moulting sites. Subnivean snow lairs for resting and breeding

\footnotetext{
*Corresponding author: meeri.koivuniemi@uef.fi
}

are situated in snowdrifts formed along shorelines of islands or islets (Helle et al. 1984). Pups are born from February to March, and weaning occurs after the ice break up in mid-May (Niemi et al. 2013a). Pups moult their lanugo hair in lairs in April during the nursing period, but the peak moulting of older seals occurs at terrestrial sites for extended haul-out events in May to June (Kunnasranta et al. 2002). The current population size estimate (320 individuals; Metsähallitus Parks \& Wildlife Finland 2015) is an expert statement based mainly on the number of lairs found in annual snow lair censuses and on observed mortality (see Sipilä 2003). Mild winters have hampered not only the breeding habitats of the seals but also the lair census method in recent years (Auttila 2015). Therefore, demands for more accurate data on

() The authors 2016. Open Access under Creative Commons by Attribution Licence. Use, distribution and reproduction are unrestricted. Authors and original publication must be credited. 
population size and other vital parameters for conservation purposes have exerted pressure and led to consideration of a non-invasive monitoring method which would not be weather dependent and would cover a larger number of seals than traditional tagging projects.

Since naturally occurring permanent features such as pelage patterns, pigmentations, nicks, notches, flipper features and scars can be used to individually identify animals, photographic identification (photoID) has been widely employed as a non-invasive method for studying long-term site fidelity, survival rates, reproduction, health, dispersal, population size and density in many vertebrates (Best \& Underhill 1990, Glockner-Ferrari \& Ferrari 1990, Langtimm et al. 2004, Karanth et al. 2006, Sarmento et al. 2009, De Boer et al. 2013, Singh et al. 2013, Gonzalvo et al. 2015). It has been especially useful in the case of large terrestrial mammals living in harsh environments (e.g. Foster et al. 2007, Kelly et al. 2008). It has also traditionally been used with marine mammals, especially cetaceans (e.g. Evans \& Hammond 2004), and it has been extended to studies of pinnipeds (Yochem et al. 1990, McConkey 1999, Forcada \& Aguilar 2000, Harting et al. 2004, Forcada \& Robinson 2006, Paterson et al. 2013). PhotoID images are typically obtained using digital single-lens reflex (DSLR) cameras, but camera traps have created new possibilities for studying species that are rare, endangered, or simply difficult or impractical to approach closely. Camera traps have been used successfully in numerous studies of terrestrial animals (O'Connell et al. 2011), but, to our knowledge, for pinnipeds this method has previously only been used in studies of Mediterranean monk seals Monachus monachus (Gucu et al. 2004, 2009a,b, Gucu 2009).

The aim of the present study was to investigate the feasibility of using photo-ID techniques to identify individuals of the Saimaa ringed seal from fur patterns, with a view to applying this approach to future population monitoring. Efforts were focused in particular on developing a camera trapping procedure for studying various ecological aspects of this rare, endangered seal. Adaptation of this technique for long-term surveying would be particularly useful, because these seals are known to moult at terrestrial haul-out sites (Kunnasranta et al. 2002), which could prove suitable as camera trap locations for inter-annual comparison purposes.

\section{MATERIALS AND METHODS}

This study was conducted in the main breeding areas of the ringed seals Phoca hispida saimensis inhabiting Lake Saimaa $\left(61^{\circ} 05^{\prime}-62^{\circ} 36^{\prime} \mathrm{N}, 2^{\circ} 15^{\prime}-\right.$ $30^{\circ} 00^{\prime} \mathrm{E}$ ) in the Haukivesi area (including Joutenvesi) in 2010-2012 and in the Pihlajavesi basin in 2013-2014, during the annual moulting season (Fig. 1). The regional population estimates based on lair censuses were 47-75 individuals in Haukivesi, 17-26 in Joutenvesi and 79-132 in the Pihlajavesi basin (Metsähallitus Parks \& Wildlife Finland 2015). The moulting season, when Saimaa ringed seals haul out throughout the day and night, enables a suitable time window for photo-ID studies whereas, during

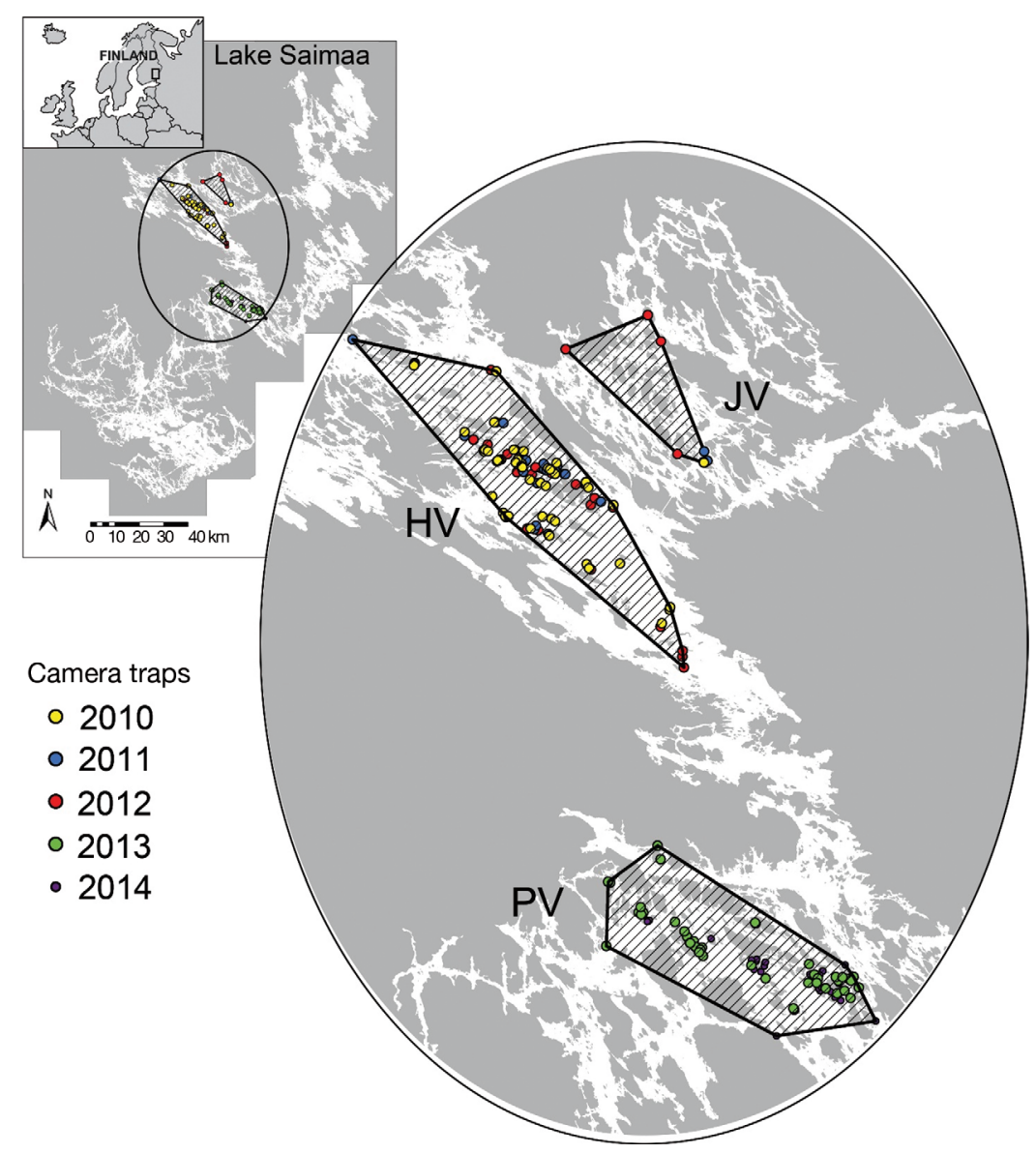

Fig. 1. Photo-ID study area and camera trapping area (polygons) on Lake Saimaa. HV: Haukivesi basin; JV: Joutenvesi basin; PV: Pihlajavesi basin 
other times of the year, haul-out patterns are less frequent and mostly nocturnal (Kunnasranta et al. 2002, Niemi et al. 2013b). All activities in the study were performed in accordance with permission from the national authority handling ethical issues concerning endangered species research.

Motion-sensitive game cameras (Scout Guard 550VB and 560K-8M with 2-4 GB memory cards) were deployed on trees or wooden sticks placed in the vicinity of observed haul-out rocks on the shorelines at a time when the sites were not occupied by seals. The distance between the camera and a resting site was kept at a minimum $(0.5-2 \mathrm{~m})$ in order to reduce the number of images accumulated due to movements of waves, grass, etc. triggering the camera. The cameras were programmed for $24 \mathrm{~h}$ operation with a delay of $0.5-2$ min between 2 successive photographs, with the aim of reducing the number of photographs and thereby economizing the memory card capacity. The cameras had passive infrared (PIR) sensors (operational distance: 2-10 m) with red or black flashes (up to 12-15 m), and were set in time stamp mode and with a high PIR sensor level. Cameras were checked 1 to 3 times a week, and, if a location had not been visited by seals for $3 \mathrm{wk}$, the camera was removed. In addition, the number of seal sightings available for examination was increased by including photographs of tagged seals and underwater videos obtained during behavioural ecology projects (Kunnasranta 2001, Rautio et al. 2009, Niemi 2013) or submitted by the general public from 1998 onwards. These photographs were typically taken during the moulting season using DSLR cameras at distances of 10-200 $\mathrm{m}$ from boats or land. Photographing from boats by researchers was also carried out during the project to maximize the number of seals observed. All seal carcasses found during the study period were also photographed and identified if the fur pattern was still visible.

After each field season the bestquality images of each event were chosen and fed into the DISCOVERY data management system (Gailey \& Karczmarski 2012). Additional information such as date, time, location, sex, age class, flipper tag number, affinities, verified death and additional photographs of the seal from different angles were fed into the database. Identifications were based mostly on ring-shaped fur patterns on the lateral sides of the seals, and individuals were identified manually by comparing 3 separate target areas (Fig. 2). Pups that had died before reaching the age of $1 \mathrm{yr}(\mathrm{n}=8)$ were excluded from the year-to-year matching data.

The distances between the individuals' haul-out sites were measured using the Point Distance Analysis tool of the ArcGIS 10.2 software (ESRI 2013). These annual and inter-annual haul-out site distances were measured only for individuals that had multiple re-sightings during the camera trapping period in different years. If the sites were on the same shoreline and the distance between them was $<200$ $\mathrm{m}$, they were merged to represent 1 haul-out site. The degree of natal site fidelity was estimated for 7 individuals that were photographed as weaned pups and later as sub-adults or adults. Haul-out site distances were measured from the natal site to all resightings after the individual's first year of life.
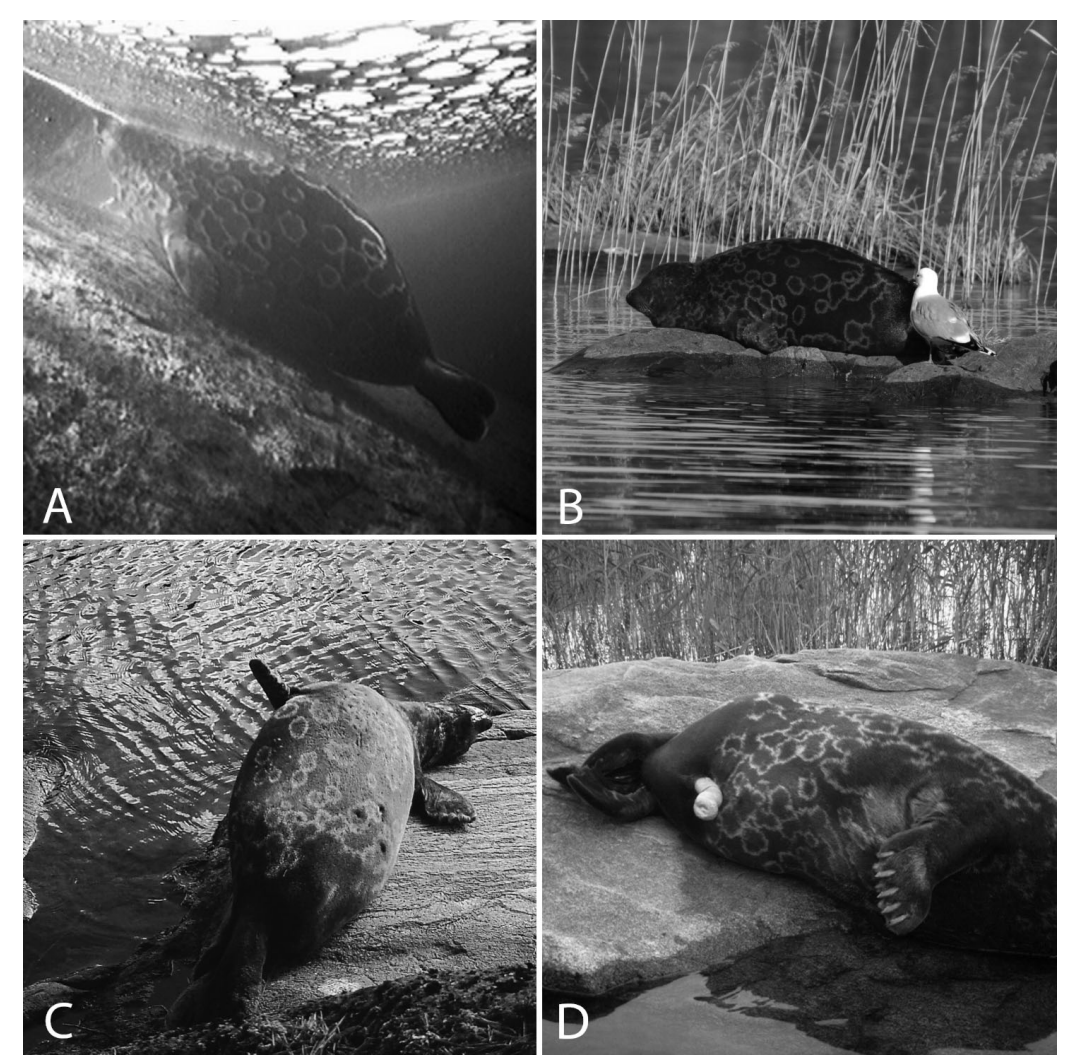

Fig. 2. Fur patterns of the Saimaa ringed seal Phoca hispida saimensis (ID: Phs016) as (A) a weaned pup in 2001 and (B) an adult in 2007, in images captured by video and a digital single-lens reflex (DSLR) camera. The genital areas of (C) an adult female (Phs166) and (D) a male (Phs010), in images captured by game cameras 


\section{RESULTS}

The total sampling effort entailed in the camera trapping conducted in the Haukivesi area for 3 successive seasons and in the Pihlajavesi basin for 2 seasons and using an average of 51 camera traps per year, was 6201 trapping days (Table 1). The annual number of cameras reflects the number of haul-out sites monitored, and the trapping periods lasted 36$56 \mathrm{~d}$ (with an average of $24 \mathrm{~d}$ per camera). All in all, $65 \%$ of the camera traps deployed captured seal images, and $<10 \%$ of the game cameras had technical problems, such as overexposed pictures, a broken switch, or interruptions in their connection to the remote controller. There was in general no need to replace batteries during sampling periods. The infrared flashes accompanying photographs taken in the dark caused no notable disturbances for the seals. The camera trapping yielded a total of around 210000 digital images of seals. In addition, around 10000 digital images of seals observed from 1998 onwards in the study areas were received from the research group and from the general public.

Both the dry and wet pelage presented distinctive patterns useful for identification, except that the sun reflecting from a wet pelage occasionally hampered identification. Both daylight pictures and some taken in the dark were used, and most of the seals were identified by their fur patterns, only 2 individuals being recognizable from other distinctive markings (scars) as well. Moreover, earlier flipper tagging of seals $(\mathrm{n}=54)$ during telemetry projects (Kunnasranta 2001, Niemi 2013) speeded up the identification process, as a total of 29 flipper-tagged seals were resighted, 23 of which were readable from the images.

Comparisons of seals in photographs from 1998 onwards and during the camera trapping periods (2010-2014) led to complete photographic identifica- tion of 164 individuals. In actual fact, 164 seals were identified from right-side images and 163 from leftside images (Fig. 2), including 138 for which images of both sides were available. To avoid possible duplicates, however, only the right-side photographs were used in later analyses. These comprised 105 individuals identified from the camera trap images and 59 identified only from the DSLR camera or underwater video data. The seals identifiable from images of both sides were obtained mostly with camera traps $(70 \%)$.

Of the 164 identifications, 86 took place in the Haukivesi area and 78 in the Pihlajavesi basin, and 42 and 29 of these, respectively, were re-sighted in subsequent years. No matches were found between the Haukivesi and Pihlajavesi areas. We were able to determine the sex of $60 \%$ of the seals from images which covered the genital areas. Of the identified seals, $37 \%$ were females, $24 \%$ males and $40 \%$ of unknown sex (Fig. 2). Pups moult their natal hair already in April; therefore, the majority of identified seals were moulting sub-adults or adults in MayJune. Most of the seals photographed (65\%) were alone at the haul-out site. In cases where 2-3 seals were seen at the same haul-out site at the same time, $36 \%$ were female-pup pairs. The deaths of 15 identified animals were verified from carcass images, including 2 cases in which the flipper tag provided evidence of death after the pelage pattern was no longer visible due to decomposition.

A total of 71 seals, representing $43 \%$ of those identified, were re-sighted at least once after 1998. Some individuals were not only re-sighted several times annually, but also inter-annually. Each individual seal was photographed an average of 2.5 times during the moulting season $( \pm 0.7 \mathrm{SD})$. During camera trapping periods (2010-2014) the re-sighting rate varied from 19 to $49 \%$ among years (Table 1). With the photographic records of seals identified prior to

Table 1. Photo-ID records and sampling effort of camera traps set for Saimaa ringed seals Phoca hispida saimensis in the Haukivesi (HV) and Pihlajavesi (PV) basins. Seal (\%): percentage of camera traps which recorded seal images; 'before' and 'during' refer to the camera trapping period; trapping days per camera data are means \pm SD. Details of new sightings and resightings during the camera trapping periods (HV: 2010-2012, PV: 2013-2014) and in previous years (since 1998)

\begin{tabular}{|c|c|c|c|c|c|c|c|c|c|c|c|c|}
\hline \multirow[t]{2}{*}{ Year } & \multirow{2}{*}{ Area } & \multirow{2}{*}{$\begin{array}{c}\text { Cameras } \\
\text { (n) }\end{array}$} & \multicolumn{4}{|c|}{ Trapping procedure } & \multirow{2}{*}{$\begin{array}{c}\text { Seals } \\
\text { identified }\end{array}$} & \multirow{2}{*}{$\begin{array}{c}\text { New } \\
\text { identifications }\end{array}$} & \multicolumn{2}{|c|}{$\begin{array}{l}\text { Old identifications } \\
\left(\text { no. of seals } \mathrm{yr}^{-1} \text { ) }\right.\end{array}$} & \multicolumn{2}{|c|}{ Re-sightings(\%) } \\
\hline & & & $\begin{array}{c}\text { Study } \\
\text { period } \\
(\mathrm{dd} / \mathrm{mm})\end{array}$ & $\begin{array}{c}\text { Total } \\
\text { trapping } \\
\text { days }\end{array}$ & $\begin{array}{c}\text { Trapping } \\
\text { days per } \\
\text { camera }\end{array}$ & $\begin{array}{l}\text { Seal } \\
(\%)\end{array}$ & & & $\begin{array}{l}\text { (no. of } \\
\text { Before }\end{array}$ & $\begin{array}{l}\text { als } \mathrm{yr}^{-1} \text { ) } \\
\text { During }\end{array}$ & During & Total \\
\hline 2010 & $\mathrm{HV}$ & 44 & $11 / 5-29 / 6$ & 1176 & $26.7 \pm 10.6$ & 59.1 & 31 & 15 & 16 & 0 & 0 & 51.6 \\
\hline 2011 & $\mathrm{HV}$ & 39 & $11 / 5-20 / 6$ & 966 & $24.8 \pm 7.4$ & 64.1 & 31 & 12 & 13 & 6 & 19.4 & 61.3 \\
\hline 2012 & $\mathrm{HV}$ & 52 & $10 / 5-25 / 6$ & 967 & $18.6 \pm 6.1$ & 71.2 & 47 & 14 & 19 & 14 & 29.8 & 70.2 \\
\hline 2013 & PV & 61 & $13 / 5-18 / 6$ & 1184 & $19.4 \pm 9.3$ & 60.7 & 46 & 42 & 4 & 0 & 0 & 8.7 \\
\hline 2014 & PV & 60 & $29 / 4-24 / 6$ & 1908 & $31.8 \pm 13.5$ & 68.3 & 45 & 19 & 4 & 22 & 48.9 & 57.8 \\
\hline
\end{tabular}


the camera trapping study included, the range of the re-sighting rate increased to $9-70 \%$ among years (Table 1). It is notable that the re-sightings in the Haukivesi area included 24 seals observed in previous telemetry studies (in 2006-2010), whereas there were only few identified individuals in the Pihlajavesi basin before 2010, which explains the low resighting rate (9\%) in the Pihlajavesi basin in 2013.

Spatial distribution and numbers of haul-out sites were determined for 54 individuals seen more than once in different camera trapping years (Table 2), yielding a mean number of haul-out sites used by 1 individual of 1.8 in a single year and 2.9 in different years. The average observed distance between the haul-out sites used by an individual seal during $1 \mathrm{yr}$ was $0.7 \mathrm{~km}$ (Table 2), while that in successive years was $1.6 \mathrm{~km}$. However, when the additional photo-ID data (including the longer time-span for 54 individuals) were taken into account, the distance between the haul-out sites was greater (average \pm SD: $2.3 \pm$ $3.1 \mathrm{~km})$, with a maximum of no less than $35.1 \mathrm{~km}$.

The re-sighting histories of 7 individuals ( 3 males and 4 females) were recorded from weaning to the age of 3-13 yr. These seals were photographed an average of 3.9 times after the first year of life, and no changes in pelage patterns were detected between the weaned pup images and adult images (see Fig. 2). The re-sightings of these individuals as subadults or adults suggest that their average dispersal distance from the natal site was $5.1 \mathrm{~km}$ (SD: \pm 1.1 ; range: $1.4-13.3 \mathrm{~km}$ ).

\section{DISCUSSION}

Camera trapping during the moulting season proved to be an effective, unobtrusive way of collecting photo-ID data. Camera traps are especially well suited for work with Saimaa ringed seals Phoca hispida saimensis, since they tend to haul out on the shore of islands, and exact trapping locations are relatively easy to define due to the animals' year-toyear site fidelity. By contrast, the haul-out sites of many other seal species are situated in harsh environments that are typically unpredictable, so photo-ID images must usually be obtained using DSLR cameras (see McConkey 1999, Harrison et al. 2006, Gerondeau et al. 2007). We suggest, however, that camera trapping could also be used with Ladoga ringed seals Phoca hispida ladogensis, which haul out on the shores throughout the summer (Sipilä et al. 1996), and probably also with several other marine species with established terrestrial haul-out sites, e.g. harbour seals Phoca vitulina (e.g. Cordes \& Thompson 2015) and grey seals Halichoerus grypus (Karlsson et al. 2005). In addition to photo-ID studies, automated camera traps can also be used for estimating levels of predation and human disturbance during breeding seasons (Auttila et al. 2014). Among field studies of pinnipeds, camera traps have previously been used only for Mediterranean monk seals Monachus monachus (Gucu et al. 2004, 2009a,b, Gucu 2009), which makes the study of Saimaa ringed seals (Auttila et al. 2014, present study) the largest pinniped camera trapping project to date.

Camera trap locations were selected based on observations of haul-out sites used by seals during the study season (Fig. 1), which increased seal image capture probabilities compared to random trap placements. The preparation of the precise sites, by trimming tall grass and removing low-hanging branches, was important for minimizing camera misfires and memory card full-ups. Where no trees were available in the vicinity, we placed cameras on wooden sticks to keep distances between seal and camera as short as possible. In addition, camera focal point pointing downwards, mainly to haul-out rocks and avoiding the effects of water movement and direct sun, effectively mitigated a large portion of misfires. In this study, memory card full-up was prevented by setting the cameras to take 2 images with a 2 min delay between capture events, which provided enough images from varied sides of the seals. We used a high sensor level in camera settings, but a low sensor level would also work with the short ranges used here. The short distance provided more accurate image data, whereas longer distances $(>3 \mathrm{~m})$ between cameras and haul-out sites produced high misfire levels, due to the movements of vegetation or waves. In addition, the camera trap did not always capture seal pictures due to low motion sensitivity over long distances.
Table 2. Annual and inter-annual numbers of haul-out sites used by individuals of the Saimaa ringed seal Phoca hispida saimensis and distances (means \pm SD) between individual sightings in the Haukivesi (HV) and Pihlajavesi (PV) basins

\begin{tabular}{|c|c|c|c|c|c|c|}
\hline \multirow[t]{2}{*}{ Area } & \multirow[t]{2}{*}{ Period } & \multirow{2}{*}{$\begin{array}{c}\text { Seals } \\
\text { (n) }\end{array}$} & \multicolumn{2}{|c|}{ Annual } & \multicolumn{2}{|c|}{ Inter-annual } \\
\hline & & & $\begin{array}{l}\text { Haul-out } \\
\text { sites (n) }\end{array}$ & $\begin{array}{l}\text { Distances } \\
(\mathrm{km})\end{array}$ & $\begin{array}{l}\text { Haul-out sites } \\
\text { sites (n) }\end{array}$ & $\begin{array}{c}\text { Distances } \\
(\mathrm{km})\end{array}$ \\
\hline HV & 2010-2012 & 31 & $1.7 \pm 0.7$ & $0.7 \pm 0.6$ & $2.8 \pm 1.1$ & $1.6 \pm 2.2$ \\
\hline PV & $2013-2014$ & 23 & $1.9 \pm 0.9$ & $0.6 \pm 0.4$ & $3.0 \pm 1.3$ & $1.5 \pm 2.2$ \\
\hline
\end{tabular}


Therefore, if larger areas, for example a haul-out site with multiple animals, must be covered via game cameras, we recommend using time-lapse-setting instead of PIR-motion sensors.

The camera traps typically provided numerous close-up images of the animal, which enhanced the quality of the data (e.g. images on both sides, genital areas), as the availability of a larger number of images for matching can improve re-sighting probabilities (Hastings et al. 2012). Our matching approach focused on identification of the lateral fur patterns of the hauled-out seals, but the ventral side (belly) and back pelage also provided distinctive patterns. Our findings indicate that fur patterns represent a distinctive feature in both sexes, and individuals can be identified from both wet and dry pelage in all moult stages. The matching of individuals was done exclusively manually, due to the varying positions of the seals and the changing camera angles, especially in the case of the camera trap images (see Fig. 2), which hindered the use of image recognition matching software (e.g. Hiby \& Lovell 1990). Due to the large number of images and growing database, however, an automated matching technique needs to be developed for this purpose (Zhelezniakov et al. 2015).

All identified Saimaa ringed seals remained within a relatively small area during the moulting season, and their fidelity to haul-out sites lasted for more than one season. The majority of the year-to-year moulting time re-sightings were made within $<2 \mathrm{~km}$. Although telemetry studies have shown sporadic movements of Saimaa ringed seals between water basins (Niemi et al. 2012), we did not observe any such movements on the part of 71 re-sighted individuals in the present study. Pups have been shown to be mobile during their first year (Niemi et al. 2013a), but the individuals studied here from weaning to maturity showed natal philopatry, i.e. stayed within an average distance of $5 \mathrm{~km}$ from their natal sites. These observations strongly support the findings of telemetric and genetic studies pointing to a high degree of site fidelity among Saimaa ringed seals (Hyvärinen et al. 1995, Kunnasranta 2001, Koskela et al. 2002, Kunnasranta et al. 2002, Niemi et al. 2012, 2013b, Valtonen et al. 2012, 2014) and highlight the vulnerability of the population to environmental change. The high re-sighting rates (Table 1) similarly confirm not only the high degree of site fidelity, but may also indicate a small population size. In 2012, for example, we identified 42 individuals only in Haukivesi basin, which is $56-76 \%$ of the population estimate for seals older than $1 \mathrm{yr}$ in that area (Metsähallitus Parks \& Wildlife Finland 2015).
To the best of our knowledge, this study represents the first application of photo-identification techniques to study ringed seals. A number of pinnipeds have lifelong permanent pelage patterns, which have been determined for example in harbour seals (Yochem et al. 1990) and grey seal females (Paterson et al. 2013). Our results confirm earlier suggestions (Hammill 2009) that the pelage patterns of ringed seals also remain consistent from weaning to adulthood, thus allowing reliable individual identification over the whole lifespan. Photo-ID enables the individuals to be recaptured without being handled, which is extremely important in the case of a threatened species. In addition, we suggest that photo-ID is likely to prove applicable to the estimation of population size and structure, as well as to studies of the dispersal, survival and behaviour of the Saimaa ringed seal. The photo-ID method can provide long-term data and make it possible to study seals during the moulting season, which is impossible by telemetry due to tag loss. As a long-term, spatially expanding monitoring technique, photo-ID data can facilitate mark-recapture analysis of population parameters and population size and can, therefore, be applied as a new population monitoring tool. Photo-ID studies extending over wider areas and covering a greater number of camera trapping years would be highly beneficial, providing a possibility for the development of citizen science and crowd-sourcing aspects. In addition, part of the Saimaa ringed seal population has already been sampled non-invasively using genetic techniques (Valtonen et al. 2015); in the future such work combined with photo-ID data (Carroll et al. 2011, Alves et al. 2013, Drechsler et al. 2015) could yield considerably deeper insights into the biology of species and advance our understanding of its small and endangered populations.

Acknowledgements. This study was supported by WWF Finland, the Raija and Ossi Tuuliainen Foundation, the Olvi Foundation, the Elma, Eino and Veikko Jumppanen Foundation, the Finnish Concordia Fund, the Kellarpelto Elementary School, the Nestori Foundation and the Kuopio Naturalists' Foundation. We thank all the people who supplied photographs and all those who worked on the camera trapping, including H. Buuri, M. Käyhkö, T. Laitinen, L. Liukkonen, M. Margaritis, T. Nisula, S. Oksanen, T. Seppäläinen, J. Taskinen, E. Uimonen, U. Uimonen and M. Vehmas. We thank L. Karczmarski and M. Valtonen for their valuable comments, and M. Hicks and I. Aho for linguistic revision. We are also grateful to the ringed seal team of Metsähallitus Parks \& Wildlife Finland for cooperation. The people belonging to the Wildlife Photo-ID Network funded by the Finnish Cultural Foundation are thanked for great inspiration. This manuscript has been greatly improved as a result of comments from 2 anonymous reviewers and the Responsible Editor J. Forcada. 


\section{LITERATURE CITED}

Alves F, Quérouil S, Dinis A, Nicolau C and others (2013) Population structure of short-finned pilot whales in the oceanic archipelago of Madeira based on photo-identification and genetic analyses: implication for conservation. Aquat Conserv Mar Freshw Ecosyst 23:758-776

Auttila M (2015) The endangered Saimaa ringed seal in a changing climate-challenges for conservation and monitoring. PhD dissertation, University of Eastern Finland, Joensuu

Auttila M, Niemi M, Skrzypczak T, Viljanen M, Kunnasranta M (2014) Estimating and mitigating perinatal mortality in the endangered Saimaa ringed seal (Phoca hispida saimensis) in a changing climate. Ann Zool Fenn 51: 526-534

Best PB, Underhill LG (1990) Estimating population size in southern right whales (Eubalaena australis) using naturally marked animals. Rep Int Whal Comm Spec Issue 12: 183-189

Carroll EL, Patenaude NJ, Childerhouse SJ, Kraus SD, Fewster RM, Baker CS (2011) Abundance of the New Zealand subantarctic southern right whale population estimated from photo-identification and genotype markrecapture. Mar Biol 158:2565-2575

Cordes LS, Thompson PM (2015) Mark-resight estimates of seasonal variation in harbour seal abundance and site fidelity. Popul Ecol 57:467-472

De Boer MN, Clark J, Leopold MF, Simmonds MP, Reijnders PJ (2013) Photo-identification methods reveal seasonal and long-term site-fidelity of Risso's dolphins (Grampus griseus) in shallow waters (Cardigan Bay, Wales). OJMS 3:66-75

Drechsler A, Helling T, Steinfartz S (2015) Genetic fingerprinting proves cross-correlated automatic photo-identification of individuals as highly efficient in large capturemark-recapture studies. Ecol Evol 5:141-151

ESRI (Environmental System Research Institute) (2013) ArcGIS Desktop 10.2. ESRI, Redlands, CA

Evans PGH, Hammond PS (2004) Monitoring cetaceans in European waters. Mammal Rev 34:131-156

Forcada J, Aguilar A (2000) Use of photographic identification in capture-recapture studies of Mediterranean monk seals. Mar Mamm Sci 16:767-793

Forcada J, Robinson S (2006) Population abundance, structure and turnover estimates for leopard seals during wiinter dispersal combining tagging and photo-identification data. Polar Biol 29:1052-1062

Foster G, Krijger H, Bangay S (2007) Zebra fingerprints: towards a computer-aided identification system for individual zebra. Afr J Ecol 45:225-227

Gailey G, Karczmarski L (2012) Discovery: photo-identification data-management system for individually recognizable animals. www.biosch.hku.hk/ecology/staffhp/ lk/Discovery/ (accessed 5 May 2014)

> Gerondeau M, Barbraud C, Ridoux V, Vincent C (2007) Abundance estimate and seasonal pattern of grey seal (Halichoerus grypus) occurrence in Brittany, France, as assessed by photo-identification and capture-markrecapture. J Mar Biol Assoc UK 87:365-372

Glockner-Ferrari DA, Ferrari MJ (1990) Reproduction in the humpback whale (Megaptera novaeangliae) in Hawaiian waters, 1975-1988: the life history, reproductive rates and behaviour of known individuals identified through surface and underwater photography. Rep Int Whal
Comm Spec Issue 12:161-169

> Gonzalvo J, Giovos I, Mazzariol S (2015) Prevalence of epidermal condition in common bottlenose dolphins (Tursiops truncatus) in the Gulf of Ambracia, western Greece. J Exp Mar Biol Ecol 463:32-38

Gucu AC (2009) Preliminary study on the effects of photo traps used to monitor Mediterranean monk seal Monachus monachus. Endang Species Res 10:281-285

Gucu AC, Gucu G, Orek H (2004) Habitat use and the preliminary demographic evaluation of the critically endangered Mediterranean monk seal (Monachus monachus) in the Cilician Basin (eastern Mediterranean). Biol Conserv 116:417-431

Gucu AC, Ok M, Sakinan S (2009a) A survey of the critically endangered Mediterranean monk seal, Monachus monachus (Hermann, 1779) along the coast of northern Cyprus. Isr J Ecol Evol 55:77-82

> Gucu AC, Sakinan S, Ok M (2009b) Occurrence of the critically endangered Mediterranean monk seal, Monachus monachus, at Olympos-Beydaglari National Park, Turkey. Zool Middle East 46:3-8

Hammill MO (2009) Ringed seal Pusa hispida. In: Perrin WF, Würsig B, Thewissen JGM (eds) Encyclopedia of marine mammals, $2^{\text {nd }}$ edn. Academic Press, San Diego, CA, p 972-974

Harrison PJ, Buckland ST, Thomas L, Harris R, Pomeroy PP, Harwood J (2006) Incorporating movement into models of grey seal population dynamics. J Anim Ecol 75: $634-645$

Harting A, Baker J, Becker B (2004) Non-metrical digital photo-identification system for the Hawaiian monk seal. Mar Mamm Sci 20:886-895

> Hastings KK, Small RJ, Pendleton GW (2012) Sex- and agespecific survival of harbor seals (Phoca vitulina) from Tugidak Island, Alaska. J Mammal 93:1368-1379

Helle E, Hyvärinen H, Sipilä T (1984) Breeding habitat and lair structure of the Saimaa ringed seal Phoca hispida saimensis Nodq. in Finland. Acta Zool Fenn 72:125-127

Hiby L, Lovell P (1990) Computer aided matching of natural markings: a prototype system for grey seals. Rep Int Whal Comm Spec Issue 12:57-61

Hyvärinen H, Hämäläinen E, Kunnasranta M (1995) Diving behavior of the Saimaa ringed seal (Phoca hispida saimensis Nordq.). Mar Mamm Sci 11:324-334

> Karanth KU, Nichols JD, Kumar NS, Hines JE (2006) Assessing tiger population dynamics using photographic capture-recapture sampling. Ecology 87:2925-2937

Karlsson O, Hiby L, Lundberg T, Jüssi M, Jüssi I, Helander B (2005) Photo-identification, site fidelity, and movement of female gray seals (Halichoerus grypus) between haulouts in the Baltic Sea. Ambio 34:628-634

Kelly MJ, Noss AJ, Di Bitetti MS, Maffei L and others (2008) Estimating puma densities from camera trapping across three study sites: Bolivia, Argentina, and Belize. J Mammal 89:408-441

Koskela JT, Kunnasranta M, Hämäläinen E, Hyvärinen H (2002) Movements and use of haul-out sites of radiotagged Saimaa ringed seal (Phoca hispida saimensis Nordq.) during the open-water season. Ann Zool Fenn 39:59-67

Kovacs KM, Aguilar A, Aurioles D, Burkanov V and others (2012) Global threats to pinnipeds. Mar Mamm Sci 28: 414-436

Kunnasranta M (2001) Behavioural biology of two ringed seal (Phoca hispida) subspecies in the large European 
lakes Saimaa and Ladoga. PhD dissertation, University of Joensuu

Kunnasranta M, Hyvärinen $\mathrm{H}$, Häkkinen J, Koskela JT (2002) Dive types and circadian behaviour patterns of Saimaa ringed seals Phoca hispida saimensis during the open-water season. Acta Theriol (Warsz) 47:63-72

Langtimm CA, Beck CA, Edwards HH, Fick-Child KJ, Ackerman BB, Barton SL, Hartley WC (2004) Survival estimates for Florida manatees from the photo-identification of individuals. Mar Mamm Sci 20:438-463

Liukko UM, Henttonen H, Hanski IK, Kauhala K, Kojola I, Kyheröinen EM, Pitkänen J (2016) Suomen nisäkkäiden uhanalaisuus 2015 - The 2015 Red List of Finnish Mammal Species. Ympäristöministeriö \& Suomen ympäristökeskus, Helsinki, p 34

McConkey S (1999) Photographic identification of the New Zealand sea lion: a new technique. N Z J Mar Freshw Res 33:63-66

Metsähallitus Parks \& Wildlife Finland (2015) Saimaannorppa (Saimaa ringed seal, in Finnish). www.metsa.fi/ saimaannorppa (accessed 15 July 2015)

Niemi M (2013) Behavioural ecology of the Saimaa ringed seal-implications for conservation. PhD dissertation, University of Eastern Finland, Joensuu

$>$ Niemi M, Auttila M, Viljanen M, Kunnasranta M (2012) Movement data and their application for assessing the current distribution and conservation needs of the endangered Saimaa ringed seal. Endang Species Res 19: 99-108

Niemi M, Auttila M, Viljanen M, Kunnasranta M (2013a) Home range, survival and dispersal of endangered Saimaa ringed seal pups: implications for conservation. Mar Mamm Sci 29:1-13

Niemi M, Auttila M, Viljanen M, Kunnasranta M (2013b) Haulout patterns of Saimaa ringed seals and their response to boat traffic during the moulting season. Endang Species Res 22:115-124

O'Connell AF, Nichols JD, Karanth KU (2011) Camera traps in animal ecology: methods and analyses. Springer, New York, NY

Paterson WD, Redman P, Hiby LA, Moss SEW, Hall AJ, Pomeroy P (2013) Pup to adult photo-ID: evidence of pelage stability in gray seals. Mar Mamm Sci 29: E537-E541

Editorial responsibility: Jaume Forcada, Cambridge, UK
Rautio A, Niemi M, Kunnasranta M, Holopainen I, Hyvärinen $H$ (2009) Vocal repertoire of the Saimaa ringed seal (Phoca hispida saimensis) during the breeding season. Mar Mamm Sci 25:920-930

Sarmento P, Cruz J, Eira C, Fonseca C (2009) Evaluation of camera trapping of estimating red fox abundance. J Wildl Manag 73:1207-1212

Singh R, Quershi Q, Kalyanasundaram S, Krausman PR, Goyal SR (2013) Use of camera traps to determine dispersal of tigers in semi-arid landscape, western India. J Arid Environ 98:105-108

Sipilä T (2003) Conservation biology of Saimaa ringed seal (Phoca hispida saimensis) with reference to other European seal populations. PhD dissertation, University of Helsinki

Sipilä T, Medvedev NV, Hyvärinen H (1996) The Ladoga seal (Phoca hispida ladogensis Nordq.). Hydrobiologia 322:193-198

Valtonen M (2014) Conservation genetics of the Saimaa ringed seal-insight into the history of a critically endangered population. $\mathrm{PhD}$ dissertation, University of Eastern Finland, Joensuu

> Valtonen M, Palo JU, Ruokonen M, Kunnasranta M, Nyman $\mathrm{T}$ (2012) Spatial and temporal variation in genetic diversity of an endangered freshwater seal. Conserv Genet 13:1231-1245

> Valtonen M, Palo JU, Aspi J, Ruokonen M, Kunnasranta M, Nyman T (2014) Causes and consequences of fine-scale population structure in a critically endangered freshwater seal. BMC Ecol 14:e22

Valtonen M, Heino M, Aspi J, Buuri H and others (2015) Genetic monitoring of a critically-endangered seal population based on field-collected placentas. Ann Zool Fenn 52:51-65

Yochem PK, Stewart BS, Mina M, Zorin A, Sadovov V, Yablokov A (1990) Non-metrical analyses of pelage pattern in demographic studies of harbor seals. Rep Int Whal Comm Spec Issue 12:87-90

Zhelezniakov A, Eerola T, Koivuniemi M, Auttila M and others (2015) Segmentation of Saimaa ringed seals for identification purposes. In: Bebis G, Boyle R, Parvin B, Koravin $\mathrm{D}$ and others (eds) Advances in visual computing. Proc 11th Int Symp ISVC, Las Vegas, NV, USA. LNCS 9475:227-236

Submitted: August 4, 2015; Accepted: January 5, 2016 Proofs received from author(s): Februar 25, 2016 